\title{
低損失誘電体および高温超電導体のミリ波評価法の開発動向
}

\author{
正 員 小林 禧夫*
}

\section{Development Trend of Millimeter-Wave Evaluation Techniques of Low-Loss Dielectrics and High Temperature Superconductors}

Yoshio Kobayashi*, Member

\begin{abstract}
Recent development trends of several resonance methods are reviewed to measure the complex relative permittivity (relative permittivity $\varepsilon_{r}$ and loss tangent tanọ of low-loss dielectric materials and the surface resistance $R_{s}$ of high temperature superconductors (HTS) in microwave and millimeter-wave regions; that is, a cavity resonator method, a cut-off circular waveguide method, a balanced-type circular disc resonator method, a Fabry-Perot open resonator method, a whispering-gallery mode resonator method, a Hakki-Coleman method, a two-dielectric-resonator method, a one-dielectric-resonator method, a dielectric resonator method using NRD-guides, and a perturbation method.
\end{abstract}

キーワード : 低損失誘電体, 複素誘電率, 高温超電導体, 表面抵抗, ミリ波, マイクロ波

Keywords : low-loss dielectric, complex permittivity, high temperature superconductor, surface resistance, millimeter-wave, micro wave

\section{1. はじめに}

マイクロ波・ミリ波デバイスの設計や新誘電体材料の開 発を行う際には, 平板状, 円柱状，丸棒状の誘電体材料の 複素比誘電率(比誘電率 $\varepsilon_{r}$, 誘電正接 $\tan \delta$ ) の温度依存性およ び周波数依存性を高精度に評価することが必要不可欠であ る。また, 最近では高温超電導体(HTS)のマイクロ波応用の 研究も盛んに行われており, その表面抵抗 $R_{s}$ を評価するこ とも重要となっている。本論文では, これらの材料評価法 の開発動向について概説する。

\section{2. 誘電体基板および円板試料の評価方法}

〈2·1〉 円筒空洞共振器法この方法は, 誘電体基板 の面方向の複素比誘電率を測定するために開発され(1) (3), 2002 年 JIS 規格として制定された ${ }^{(4)}$ 。図 1 にその構成図を示 す。この構造は, 導体円筒空洞を 2 つに分割しその間に誘 電体基板を挟んで共振器を構成するため, 測定試料の着脱 が容易であり，非破壊測定に有効である。 $\varepsilon_{r}$ は $\mathrm{TE}_{011}$ モード の共振周波数 $f_{0}$ の測定值より, $\tan \delta$ は無負荷 $Q, Q_{u}$ の測定值 より求められる。この際, 試料と空洞端部に存在する縁端 効果は, Ritz-Galerkin 法による厳密解析により正確に評価さ れるため, 高精度測定が実現される。また, 文献(3), (8)に示 される自動測定システムを用いることにより, 複素比誘電 率の温度依存性を高精度かつ高能率に測定可能である。

\section{$\langle 2 \cdot 2\rangle$ 遮断円筒導波管法この方法は, 円筒空洞共}

\footnotetext{
* 埼玉大学工学部

テ338-8570＼cjkstart埼玉県さいたま市桜区下大久保 255

Saitama University, Faculty of engineering

255 Shimo-ohkubo, Sakura-ku, Saitama-shi 338-8570
}

振器がミリ波帯で製作困難になるために開発された測定法 であり, 誘電体基板の面方向の複素比誘電率が測定可能で ある(5) (11)。現在, JIS 原案として審議されている。図 2 に



左:空洞共振器右:誘電体を装荷した共振器

図 1 円筒空洞共振器法



(a) 誘電体を装荷した共振器 (b) 空洞共振器

図 2 遮断円筒導波管法 

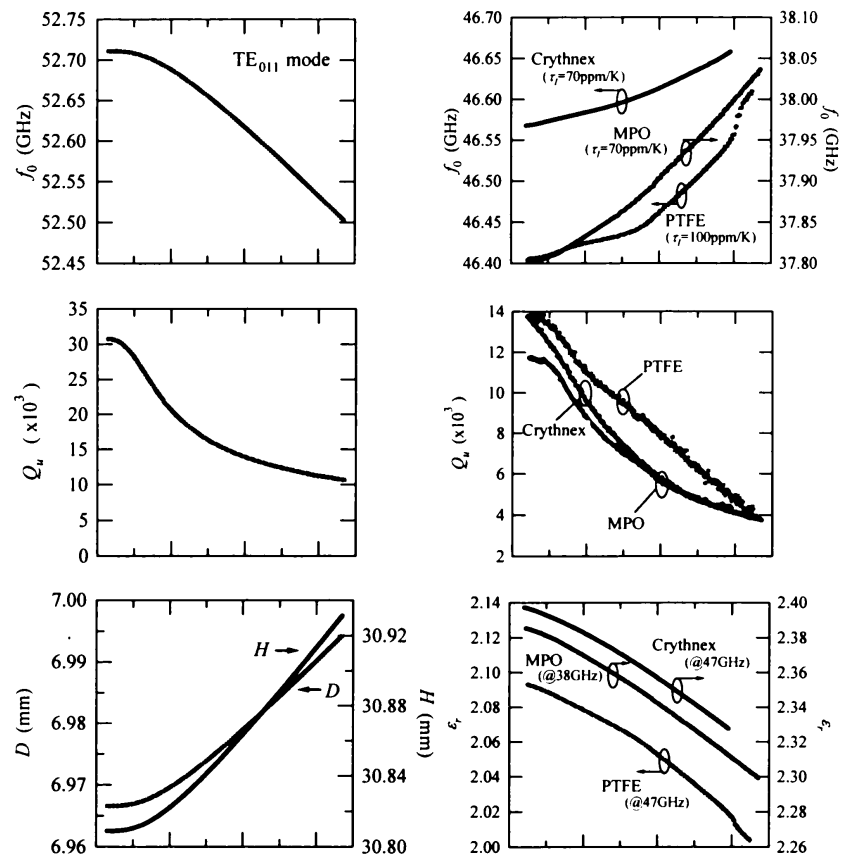



(a) 空洞共振器

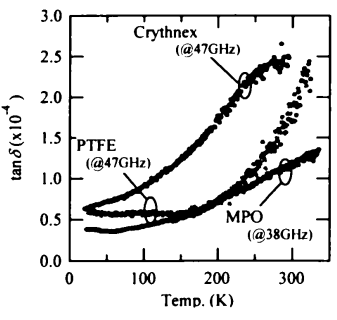

(b) 3 種類の有機材料
図 3 遮断円筒導波管法による空洞共振器および 3 種類の 有機材料の温度依存性の測定結果

その構成図を示す。 $\varepsilon_{r}$ は $\mathrm{TE}_{011}$ モードの $f_{0}$ の測定值より, $\tan \delta$ は $Q_{u}$ の測定值より縁端効果まで考慮した值が求められる。 一例として本法により評価した PTFE 平板, Crythnex 平板, MPO (Modified Polyolefin)平板の複素比誘電率の温度依存性 の測定結果を図 3 に示す。


基板に対して垂直な電界成分を持つ $\mathrm{TM}_{010}$ モードを用いる ため，基板の厚さ方向の複素比誘電率を測定することがで きる ${ }^{(12) \sim(16)}$ 。この共振器は, 図 4 に示すように, 厚さ $t$, 暑 さ方向の比誘電率 $\varepsilon_{z}$ の 2 枚の誘電体基板の間に直径 $2 R$ の導 体円板を挟み，これを 2 枚の導体板で挟んで構成される。 従来は, ストリップ線路を用いて導体円板の側面から励振 していたため, 薄い誘電体基板の測定に際しては線路幅が 狭くなりコネクタとの整合性に問題があった。また高損失 材料を評価する場合，モード判別が困難であった。これら を解決するために, 同軸線路により円板の軸方向から励振 を行う方法が提案された ${ }^{(15)(16)}$ 。この方法では, 円板の中心 に電界成分を持つ $\mathrm{TM}_{0 \mathrm{~m} 0}$ モードが選択的に励振されるため, 薄い基板や高損失材料に対しても高精度測定が可能である。

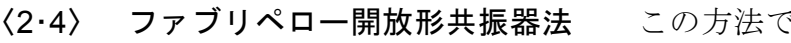

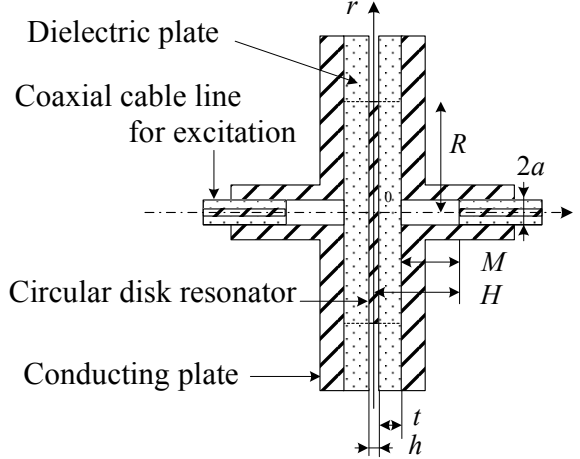

図 4 同軸励振平衡形円板共振器法

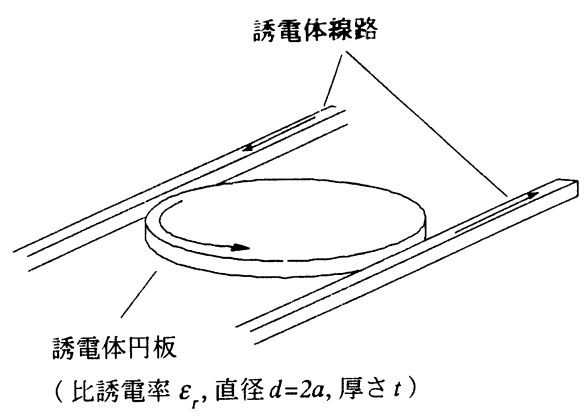

図 5 WG モード共振器法

は，2 枚の球面反射鏡を用いて開放形共振器を構成する。 1 $\sim 3 \times 10^{5}$ 程度の高 $Q$ 值が実現できるが, 反射鏡-平板試料間 の平行度を微妙に調整する必要があり, 取扱いに熟練を要す る(17) (20)。50 GHz 帯では $75 \mathrm{~mm}$ 角程度の平板試料が必要とな り, 測定周波数が低くなると共振器および測定装置が更に 大型化する。そのため，本法はミリ波帯以上で有効である。

〈2.5〉 ウィスパリングギャラリー(WG)モード共振器法

図 5 にWG モード誘電体共振器の構成図を示す。誘電体 円板の縁付近に励振用の誘電体線路を近づけると, 円板内 を周方向に伝搬する進行波共振が生じる。円板の直径を媒 質内波長の数十倍, 厚さを半波長程度にすると, WG モード 以外の共振モードは漏洩モードとなり, WG モードの共振ピ 一クのみが周方向モード次数の順に現れる。このとき， $\varepsilon_{r}$ はモード次数および $f_{0}$ の測定值より, また $\tan \delta$ は $Q_{u}$ の測定 值より求められる。

この方法では共振器の構成に遮蔽導体を用いないため, ミリ波帯における導体板損失の影響を受けることがなく，

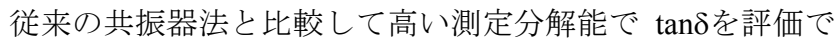
きる(21) (25)。また, 測定に使用する共振モードが一定の周波 数間隔で現れるため, 複素比誘電率の周波数依存性の測定 が容易に行える。

\section{3. 誘電体円柱試料の評価方法}

〈3·1〉 Hakki-Coleman 法この方法は, その簡便さ から低損失誘電体円柱の面方向の $\varepsilon_{r}$ および $\tan \delta$ の評価方法 




図 6 誘電体円柱の複素比誘電率測定に用いる 誘電体円柱共振器の構造

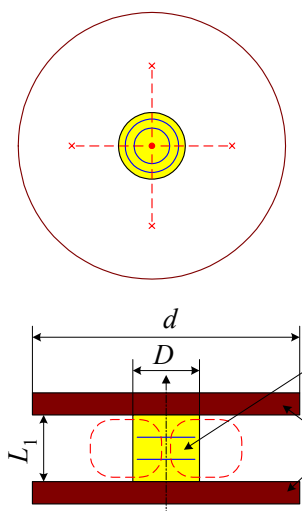

(a) $\mathrm{TE}_{011}$ mode resonator
Electric field line

Magnetic field line

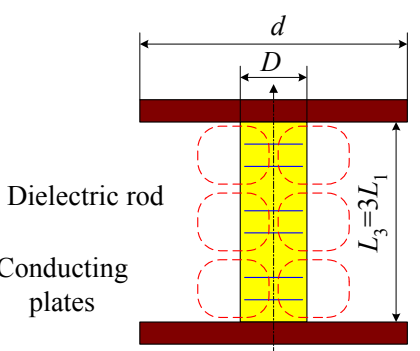

(b) $\mathrm{TE}_{013}$ mode resonator
図 72 誘電体円柱共振器法

として広く用いられている ${ }^{(26)(27)}$ 。測定に用いられる共振器 は, 図 6 に示すように, 直径 $D$, 長さ $L$ の誘電体円柱を $R_{s}$ が等しい 2 枚の平行導体板の間に装荷し，板バネあるいは マイクロメータにより固定して構成される。本測定では, 導体板と円柱間の空隙効果を避けるため導体板に平行な電 界成分のみを持つ $\mathrm{TE}_{0 \mathrm{mp}}$ モードを用いる。円柱の $\mathcal{E}_{r}$ は, $\mathrm{TE}_{0 \mathrm{mp}}$ モードの共振周波数 $f_{0 \mathrm{mp}}$ より求められる。また $\tan \delta$ は, $\mathrm{TE}_{0 \mathrm{mp}}$ モードの無負荷 $Q, Q_{u 0 \mathrm{mp}}$ の測定值から, 銅板の比導電率(パ 一セント導電率) $\sigma_{r}$ を $100 \%$ と仮定することにより求められ る。ただし， $\sigma_{r}$ は万国標準軟銅の導電率 $\sigma_{0}\left(=58 \times 10^{6} \mathrm{~S} / \mathrm{m}\right)$ に対する比の百分率であり, $R_{s}=\left(50 \omega \mu / \sigma_{0} \sigma_{r}\right)^{1 / 2}$ の関係があ る。しかしマイクロ波帯では, 表皮効果により電流は導体 表面しか流れないため, 導体表面の酸化および表面粗さ等 により $\sigma_{r}$ の実効的な值は $100 \%$ 以下となる。これにより，本

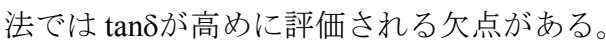

〈3.2〉 2 誘電体円柱共振器法 Hakki-Coleman 法によ る $\tan \delta$ 測定法を改善するために, 2 誘電体円柱共振器法が開 発された ${ }^{(28)}$ 。この方法では直径が等しい 2 つの誘電体円柱 を用いることにより，円柱の $\tan \delta$ と導体板の $R_{s}$ を高精度に 分離測定することができる。図 7 に示すように $\mathrm{TE}_{011}$ モード 用円柱は長さ $L_{1}$ を持ち, $\mathrm{TE}_{013}$ モード用円柱は長さ $L_{3}=3 L_{1}$ を持つ。円柱の $\varepsilon_{r}$ は各共振器の $f_{0}$ の測定值より求められる。 また，2つの円柱の $\tan \delta か ゙$ 等しいと仮定することにより，両共 振器の $Q_{u}$ の測定值から $\tan \delta$ おび $R_{s}$ を求めることができる。

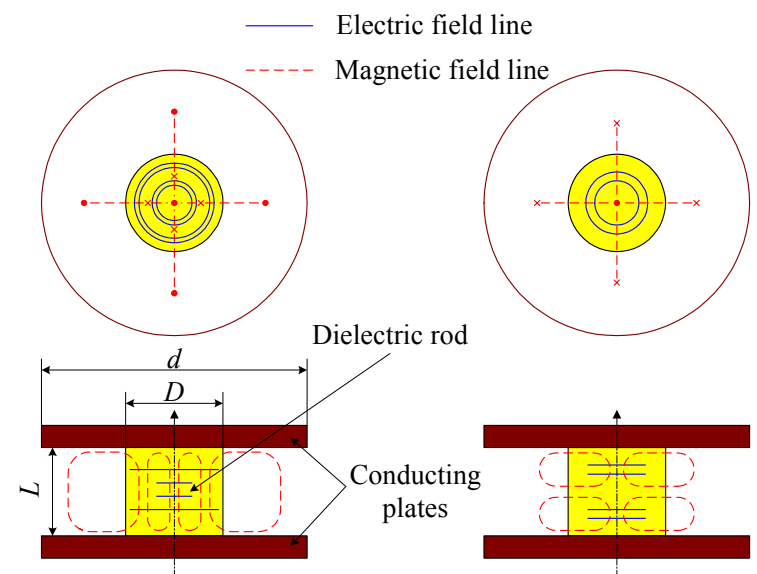

(a) $\mathrm{TE}_{021}$ mode

(b) $\mathrm{TE}_{012}$ mode
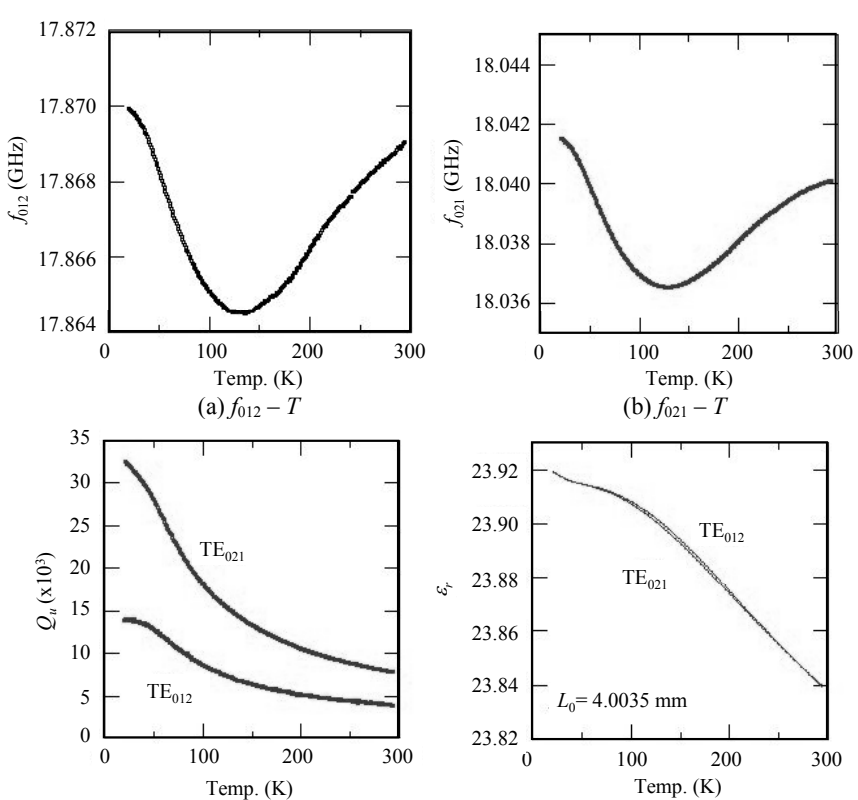

(c) $Q_{u}-T$



(e) $\tan \delta-T$

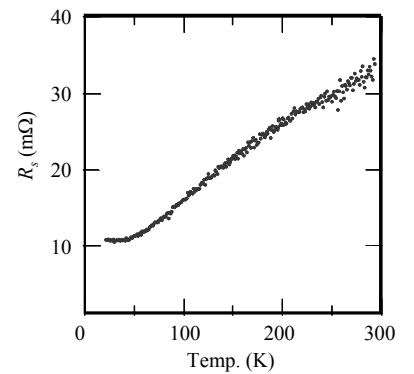

(f) $R_{s}-T$

図 91 誘電体円柱共振器法による BMT セラミック円柱 の $\varepsilon_{r}, \tan \delta$ おび銅板の $R_{s}$ の測定結果

なお, 本法はラウンドロビン試験を行った後 ${ }^{(29)}, 1996$ 年に JIS 規格 ${ }^{(30)}$ および 1999 年に IEC 国際規格 ${ }^{(31)}$ としてそれぞれ 制定された。また, この測定法用標準セラミック共振器は, JFCC(ファインセラミックスセンター)に準備されている。 
〈3·3〉 1 誘電体円柱共振器法 一般に, 等しい $\tan \delta$ を持つ円柱を複数個揃えるのは容易でない。これを解決す るために, 1 誘電体円柱共振器法が提案された ${ }^{(32)(33)}$ 。本法 では図 8 に示すように一つの誘電体円柱共振器内に存在す る $\mathrm{TE}_{012}$ および $\mathrm{TE}_{021}$ モードが用いられる。これらの共振モ ードは高次モードであり, 共振器寸法の設計には他の隣接 モードの影響を受けないようにモードチャートを用いて正 確に行う必要がある(33)。円柱の $\varepsilon_{r}$ は $f_{0}$ の測定值より求めら れ, $\tan \delta$ おび $R_{s}$ は両モードの $Q_{u}$ から求められる。一例と して, 本測定法により評価した BMT セラミック円柱の測定 結果を図 9 に示す。

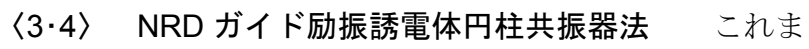
で述べた方法をミリ波帯に応用すると, 円柱の高さよりも 同軸線路の直径が大きくなり測定が困難になる。これを解 決するために, NRD ガイド (34)を用いた誘電体円柱共振器法 が開発された ${ }^{(35)(36)}$ 。この方法では, 誘電体円柱共振器とリ ング共振器を用いて円柱の $\varepsilon_{r}, \tan \delta$ おび導体板の $\sigma_{r}$ を求め る。しかし， $\varepsilon_{r}$ の計算が複雑であり，また， $\sigma_{r}$ の測定精度が あまり高くないため $\tan \delta の$ 測定精度が低いなどの問題があ った。最近, 誘電体円柱の $\tan \delta$ と導体板の $\sigma_{r}$ を簡便かつ高 精度に分離測定するために図 10 に示す新しい方法が提案さ れた ${ }^{(37)}$ 。本測定法では， $\mathrm{TE}_{021}$ モード用および $\mathrm{TE}_{02 \delta}$ モード 用の 2 つの共振器が用いられる。

〈3.5〉 $\mathrm{TM}_{010}$ モード円筒空洞共振器を用いた摂動法

図 11 に示される $\mathrm{TM}_{010}$ モード円筒空洞共振器を用いた捸 動法は，その簡便さからマイクロ波帯における誘電体丸棒 試料の $z$ 軸方向の複素比誘電率測定法として広く用いられ ている( ${ }^{(38)}$ 。最近, Ritz-Galerkin 法による厳密解析を行うこと により,この共振器の試料挿入孔の影響を考慮したより高 精度な摂動法が提案された(39)。またこの方法は, 液体の複

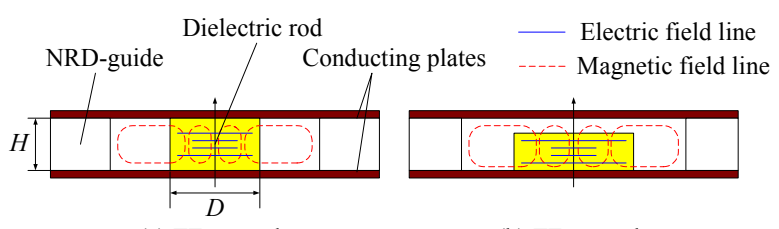

(a) $\mathrm{TE}_{021}$ mode

(b) $\mathrm{TE}_{02 \delta}$ mode

図 10 NRD ガイド励振誘電体円柱共振器

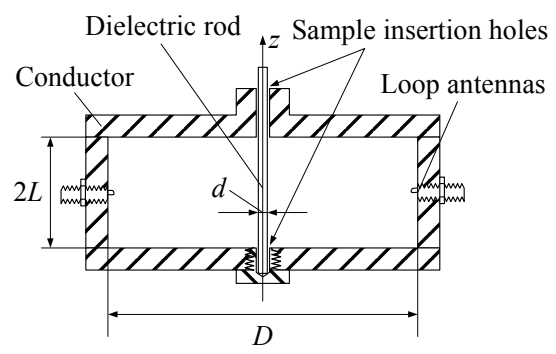

図 $11 \mathrm{TM}_{010}$ モード円筒空洞共振器を用いた摂動法
素比誘電率測定にも有効であることが実証された ${ }^{(40)}$ 。

\section{4. 高温超電導体の評価方法}

$\langle 4 \cdot 1\rangle$ Hakki-Coleman 法の応用 $\langle 3 \cdot 1\rangle$ 節で述べら れた Hakki-Coleman 法は HTS 膜の $R_{s}$ 測定にも応用され た(41)〜(45)。共振器は 2 枚の HTS 膜の間にサファイアや $\mathrm{LaAlO}_{3}$ などの低損失誘電体円柱を挟むことにより構成され る。この方法では, $\tan \delta=0$ と仮定することにより $\mathrm{TE}_{011}$ モー ドの $Q_{u}$ から HTS の $R_{s}$ を評価する。しかし, $10 \mathrm{GHz}$ で $R_{s}=$ $0.1 \mathrm{~m} \Omega$ 以下の HTS を評価する際には, 次節で述べる 2 サフ アイア円柱共振器法に対し $4 \%$ 程度の誤差を生じる ${ }^{(47)}$ 。

〈4·2〉 2 サファイア円柱共振器法＼cjkstart先に述べた 2 誘 電体円柱共振器法は, $(\mathrm{Zr}, \mathrm{Sn}) \mathrm{TiO}_{4}$ セラミック円柱を用いる ことにより HTS バルクの $R_{S}$ 測定にも応用された(46)。しかし, $10 \mathrm{GHz}$ で $R_{s}=0.1 \mathrm{~m} \Omega$ 以下の $\mathrm{HTS}$ 薄膜が開発されると, 薄膜 に比べ円柱の損失が大きくなるためセラミック円柱の代わ りに低損失サファイア円柱が用いられるようになった。こ の方法は 2 サファイア円柱共振器法と呼ばれ(47)(48), 2001 年 IEC 国際規格 ${ }^{(49)}$ に採用された。この国際規格では， $Q_{u}>10^{6}$ 以上の高 $\mathrm{Q}$ 測定に対しては図 12 に示す closed-type サファイ ア円柱共振器が用いられる。サファイア円柱は下部 HTS 膜 の中央に配置され，上部 HTS および無酸素銅リングにより

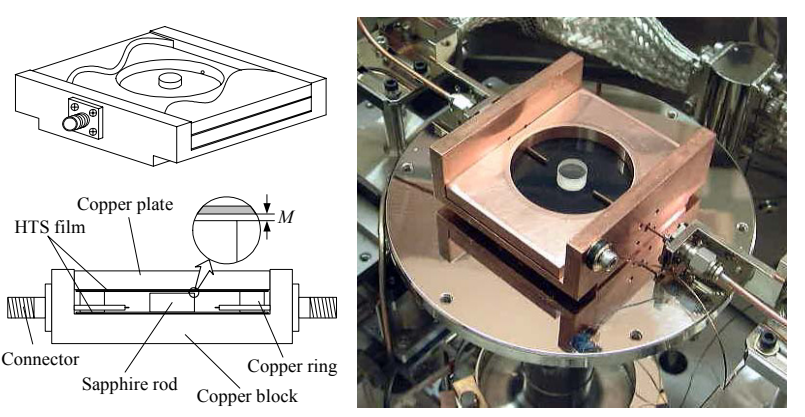

図 12 closed-type サファイア円柱共振器

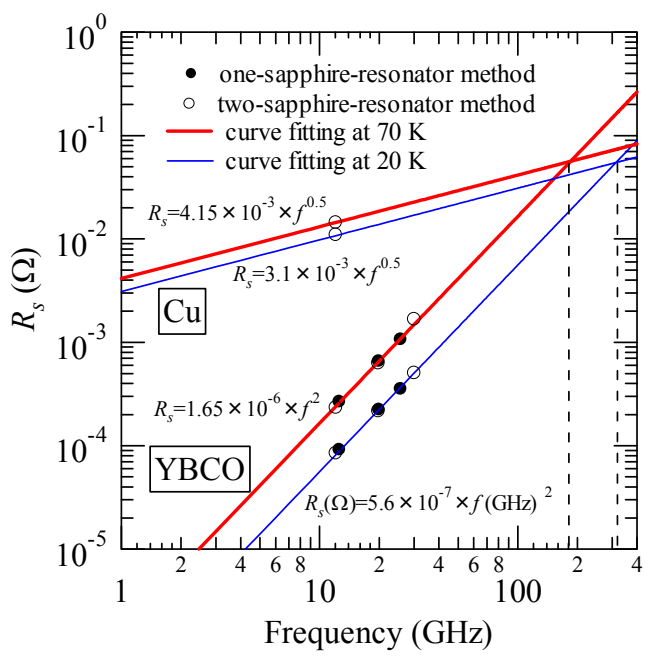

図 $13 \mathrm{YBCO}$ 薄膜および銅板の $R_{S}$ の周波数依存性測定結果 
遮蔽される。ここで, 円柱と上部 HTS の間の空隙は $M$ とす る。サファイアの一軸異方性を考慮した共振器の最適設計は, モードマッチング法による厳密解析により行われている ${ }^{(50)}$ 。

〈4·3〉 1 サファイア円柱共振器法 最近, HTS の $R_{s}$ の周波数依存性を評価するために, 1 個のサファイア円柱共 振器内に存在する 4 つの $\mathrm{TE}_{0 \mathrm{mp}}$ モードを用いる 1 サファイア 円柱共振器法が提案された ${ }^{(51) \sim(53)}$ 。これにより 1 個のサファ イア円柱のみを用いて 3 点の周波数における $R_{s}$ が測定可能 となった。

最後に, 2 サファイア円柱共振器法および 1 サファイア円 柱共振器法により測定した同一の $\mathrm{YBa}_{2} \mathrm{Cu}_{3} \mathrm{O}_{7}(\mathrm{YBCO})$ 薄膜 および銅板の $R_{s}$ の周波数依存性測定結果を図 13 に示す。図 より，30 GHz における YBCO の $R_{s}$ は銅板の約 $1 / 20$ である ことが分かった。これにより, HTS 膜をミリ波デバイスに 応用することも期待できる。

\section{5. 測定法の適用範囲および測定精度}

これまでに述べた測定法の適用範囲および測定精度を表 1 および表 2 にまとめる。

表 1 複素比誘電率測定法の適用範囲および測定精度

\begin{tabular}{|c|c|c|c|}
\hline 測定法名 & $f_{0}(\mathrm{GHz})$ & $\begin{array}{c}\varepsilon_{r} \\
\frac{\Delta \varepsilon_{\gamma}}{\varepsilon_{\gamma}}(\%)\end{array}$ & $\begin{array}{c}\tan \delta \\
\frac{\Delta \tan \delta}{\tan \delta}(\%)\end{array}$ \\
\hline 円筒空洞共振器法 & $2 \sim 40$ & $\begin{array}{c}1.1 \sim 50 \\
\pm 0.2 \sim 0.5\end{array}$ & $\begin{array}{l}10^{-3} \sim 10^{-6} \\
\pm 2 \sim 10\end{array}$ \\
\hline 遮断円筒導波管法 & $30 \sim 100$ & $\begin{array}{c}1.1 \sim 50 \\
\pm 0.2 \sim 1.0\end{array}$ & $\begin{array}{l}10^{-3} \sim 10^{-6} \\
\pm 2 \sim 10\end{array}$ \\
\hline 平衡形円板共振器法 & $2 \sim 30$ & $\begin{aligned} 1.1 & \sim 10 \\
\pm 0.2 & \sim 1.0\end{aligned}$ & $\begin{array}{l}10^{-2} \sim 10^{-4} \\
\pm 5 \sim 20\end{array}$ \\
\hline $\begin{array}{c}\text { ファブリペロー開放形 } \\
\text { 共振器法 }\end{array}$ & $40 \sim 300$ & $\begin{array}{l}1.1 \sim 50 \\
\sim \pm 0.5\end{array}$ & $\begin{array}{c}10^{-2} \sim 10^{-4} \\
\sim \pm 10\end{array}$ \\
\hline WG モード共振器法 & $40 \sim 150$ & $\begin{array}{l}2 \sim 50 \\
\sim \pm 2.0\end{array}$ & $\begin{array}{c}10^{-2} \sim 10^{-5} \\
\sim \pm 10\end{array}$ \\
\hline 2 誘電体円柱共振器法 & $2 \sim 40$ & $\begin{array}{l}2 \sim 1000 \\
\pm 0.2 \sim 0.5\end{array}$ & $\begin{array}{l}10^{-3} \sim 10^{-7} \\
\pm 5 \sim 20\end{array}$ \\
\hline 1 誘電体円柱共振器法 & $2 \sim 50$ & $\begin{array}{l}2 \sim 1000 \\
\pm 0.2 \sim 1.0\end{array}$ & $\begin{aligned} 10^{-3} & \sim 10^{-7} \\
\pm 5 & \sim 20\end{aligned}$ \\
\hline $\begin{array}{c}\text { NRD ガイド励振 } \\
\text { 誘電体円柱共振器法 }\end{array}$ & $30 \sim 100$ & $\begin{array}{l}2 \sim 50 \\
\sim \pm 0.4\end{array}$ & $\begin{array}{c}10^{-3} \sim 10^{-6} \\
\sim \pm 10\end{array}$ \\
\hline $\begin{array}{c}\mathrm{TM}_{010} \text { 空洞共振器を } \\
\text { 用いた摂動法 }\end{array}$ & $1 \sim 30$ & $\begin{array}{c}1.1 \sim 50 \\
\pm 1.0 \sim 7.0\end{array}$ & $\begin{array}{l}10^{-2} \sim 10^{-4} \\
\pm 10 \sim 30\end{array}$ \\
\hline
\end{tabular}

表 2 HTS 膜の表面抵抗測定法の適用範囲および測定精度

\begin{tabular}{|c|c|c|c|}
\hline 測定法名 & $f_{0}(\mathrm{GHz})$ & $\begin{array}{c}R_{s}(\mathrm{~m} \Omega) \\
\text { at } 12 \mathrm{GHz}\end{array}$ & $\frac{\Delta R_{s}}{R_{s}}(\%)$ \\
\hline Hakki-Coleman 法 & $5 \sim 30$ & $>0.1$ & $\pm 10 \sim 50$ \\
\hline 2 サファイア円柱共振器法 & $10 \sim 30$ & $>0.06$ & $< \pm 10$ \\
\hline 1 サファイア円柱共振器法 & $7 \sim 45$ & $>0.06$ & $< \pm 10$ \\
\hline
\end{tabular}

\section{6. まとめ}

マイクロ波・ミリ波帯における低損失誘電体材料の複素 比誘電率およびHTS の $R_{S}$ の評価法の開発動向について述べ た。本論文に示した測定法を適切に用いることにより，高 精度な材料評価が可能となり材料開発に大きく貢献できる と考える。

\section{謝 辞}

論文執筆にご協力頂いた本研究室院生の橋本経君, 清水 隆志君に深謝します。

(平成 15 年 11 月 20 日受付)

\section{文献}

<誘電体基板材料の評価方法 $>$

(円筒空洞共振器法)

（1）小林禧夫・佐藤純也：「空洞共振器による誘電体平板材料の複素誘電 率の非破壊測定」，信学技報, MW87-53, pp. 41-48 (1987)

(2) Y. Kobayashi and J. Sato : "Complex permittivity measurement of dielectric plates by a cavity resonance method", IEICE Tech. Rep., MW88-40, pp.43-50 (1988)

(3) G. Zhang and Y. Kobayashi : "Complex permittivity measurement of unknown dielectric plates by the cavity resonance method", Proc. 3rd Int. Conf. on Electronic Measurement \& Instruments (ICEMI '97), pp.470-473 (1997)

(4) JIS R1641 (2002):「ファインセラミックス基板のマイクロ波誘電特性 の試験方法

(遮断円筒導波管法)

(5) Y. Kobayashi and T. Hataguchi : "Millimeter wave measurement of complex permittivity by dielectric disk resonator method", The 9th International Conf. Infrared and Millimeter Waves Dig., TH4-8, pp.374-375 (1984)

(6) G. Zhang, S. Nakaoka, and Y. Kobayashi : "Millimeter wave measurements of temperature dependence of complex permittivity of dielectric plates by the cavity resonance method", 1997 Asia Pacific Microwave Conf. Proc., pp.913-916 (1997)

(7) Y. Kobayashi and T. Shimizu : "Millimeter wave measurements of temperature dependence of complex permittivity of dielectric plates by the cavity resonance method", 1999 IEEE MTT-S Int. Microwave Symp. Dig., pp.1885-1888 (1999)

(8) T. Shimizu and Y. Kobayashi : "Millimeter wave measurements of temperature dependence of complex permittivity of GaAs plates by a circular waveguide method", 2001 IEEE MTT-S Int. Microwave Symp. Dig., THIF-51, pp.2195-2198 (2001)

(9) T. Shimizu and Y. Kobayashi : "Millimeter wave measurements of some low-loss dielectric plates by a novel cut-off circular waveguide method", 32nd European Microwave Conf. Proc., pp.825-828 (2002)

(10) T. Shimizu, Z. Ma, and Y. Kobayashi : "Design of a grooved circular cavity for dielectric substrate measurements in millimeter wave region", IEICE Trans. Electron., Vol.E86-C, No. 8, pp.1715-1720 (2003)

(11) T. Shimizu, T. Nishino, and Y. Kobayashi : "Some discussions of the resonator structure for the cut-off waveguide method and the round robin test," 33rd European Microwave Conf. Proc. (2003)<to be published>

(平衡形円板共振器法)

(12) K. Tanabe, Y. Kobayashi, and S. Tanaka : "Numerical Analysis of Eigenvalue Solution of Disk Resonator", IEEE Trans. Microwave Theory and Tech., Vol. MTT-23, pp.508-511 (1975)

(13) 小林禧夫・于 静 :「平衡形円板共振器による複素誘電率の自動測 定」, 信学技報, MW91-117 (1991)

(14) Y. Kobayashi and J. Yu : "Temperature- dependence measurement of anisotropic complex permittivity for MIC dielectric substrate", 1992 Asia-Pacific Microwave Conf. Proc., No.39-2, pp.859-862 (1992)

(15) 川端広一・小林禧夫: 「同軸励振平衡形円板共振器を用いた誘電体平 板の複素誘電率測定」, 信学技報, MW2000-157, pp.43-50 (2000) 
(16) H. Kawabata and Y. Kobayashi : "The analysis of a balanced-type circular disk resonator excited by coaxial cable lines to measure the complex permittivity", 2001 Asia-Pacific Microwave Conf. Proc., pp.1322-1325 (2001)

(ファブリペロー開放形共振器法)

(17) L. Cullen and P. K. Yu : "The accurate measurement of permittivity by mean of an open resonator", Proc. Roy Soc. A, vol.325, pp.493-509 (1971)

(18) Ph. Coquest, T. Matsui, and M. Kiyokawa : "Dielectric Measurement in the $60-\mathrm{GHz}$ Band Using a High-Q Gaussian Beam Open Resonator", IEICE Trans. On Electronics, E78-C, pp.1125-1130 (1990)

(19) 松井敏明 :「ガウシアンビーム共振器法」, 信学ソ大, PC-1-6, pp.317-318 (1999)

(20) M. N. Afsar, H. Chi, X. H. Li, and T. Matsui : "A 60GHz open resonator system for dielectric measurement", Proc. 1989 European Microwave Conf., pp.820-823 (1989)

(ウィスパリングギャラリーモード共振器法)

(21) 古神義則・松村和仁：「ウィスパリングギャラリーモード共振器を用 いたミリ波誘電体材料の温度特性の測定」, 信学総大, C-2-120, pp.171 (2000)

(22) 古神義則・田村 先・松村和仁：「ウィスパリングギャラリーモード 共振器による $100 \mathrm{GHz}$ 帯複素誘電率測定」, 信学論, J84-C, No.8, pp.703-706 (2001)

(23) 古神義則・松村和仁：「ウィスパリングギャラリーモード共振器を用 いた低誘電率誘電体材料のミリ波複素誘電率測定」, 信学論, J83-C, No.6, pp.553-558 (2000)

（24）田貝雅樹・古神義則・松村和仁：「ウィスパリングギャラリーモード 共振器法による誘電体材料の温度特性評価に関寸る検討」, 信学ソ 大, C-2-78, pp.102 (2001)

(25) Y. Kogami, H, Tamura, and K. Matsumura : "Measurements of complex permittivities in $100 \mathrm{GHz}$ band by the Whispering-gallery mode resonator method", IEICE Trans., Vol.J84-C, No.8, pp.703-706 (2001)

＼cjkstart誘電体円柱材料の評価方法 $>$

(Hakki-Coleman 法)

(26) B. W. Hakki and, P. D. Coleman : "A dielectric resonator method of measuring inductive capacities in the millimeter range", IRE Trans. Microwave Theory Tech., Vol.MTT-8, pp.402-410 (1960)

(27) W. E. Courtney : "Analysis and evaluation of a method of measuring the complex permittivity and permeability of microwave insulators", IEEE Trans. Microwave Theory Tech., Vol.MTT-18, pp.476-485 (1970)

( 2 誘電体円柱共振器法)

(28) Y. Kobayashi and M. Katoh : "Microwave measurement of dielectric properties of low-loss materials by the dielectric rod resonator method", IEEE Trans. Microwave Theory Tech., Vol.MTT-33, No.7, pp.586-592 (1985)

(29) Y. Kobayashi and H. Tamura : "Round robin test on a dielectric resonato method for measuring complex permittivity at microwave frequency", IEICE Trans. Electron., Vol.E77-C, No.6, pp.882-887 (1994)

(30) JIS R 1627 (1996) : Testing method for dielectric properties of fine ceramics at microwave frequency

(31) IEC 61338-1-3 (1999) : Measurement method of complex relative permittivity for dielectric resonator materials at microwave frequency

(1 誘電体円柱共振器法)

(32) D. $\mathrm{Xu}$ and $\mathrm{Z}$. Li : "A novel method for characterizing the surface resistance of two conducting plates shorted at both ends of a dielectric resonator", $15^{\text {th }}$ European Microwave Conf. Proc., pp.912-916 (1985)

(33) Y. Kobayashi and H. Yoshikawa : "Microwave measurements of surface impedance of high- $T_{C}$ superconductors using two modes in a dielectric rod resonator", IEEE Trans. Microwave Theory Tech., Vol.46, No.12, pp.2524-2530 (1998)

(NRD ガイド励振誘電体円柱共振器法)

(34) T. Yoneyama and S. Nishida : "Nonradiative dielectric waveguide for millimeter-wave integrated circuit", IEEE Trans. Microwave Theory Tech., Vol.MTT-29, pp.1188-1192 (1981)

(35) 石川容平・田中裕明・西田 浩・西川敏夫 :「NRD ガイドを用いた ミリ波用誘電体共振器材料の複素誘電率測定法」，信学技報， MW90-13, pp.31-36 (1990)

（36）石川容平・谷崎 透・斉藤 篤・米山 務：「NRD ガイドを用いた ミリ波誘電体材料の複素誘電率測定」, IEICE Trans. Commun., Vol.J78-C-I, No.9, pp.418-429 (1995)

(37) O. Nakayama, A. Fukuura, and M. Nishimura : "Millimeter-wave measurement of complex permittivity using dielectric rod resonator excited by NRD-guide", IEEE Trans. Microwave Theory Tech., Vol.51, No.1, pp.170-177 (2003)
$\left(\mathrm{TM}_{010}\right.$ モード円筒空洞を用いた摂動法

(38) J. Estin and H. E. Bussy : "Errors in dielectric measurements due to a sample insertion hole in a cavity", IRE Microwave Theory Tech., Vol.MTT-8, pp.650-653 (1960)

(39) K. Kawabata, H. Tampo, and Y. Kobayashi : "An improved perturbation method using a $\mathrm{TM}_{010}$ mode cylindrical cavity", Asia-Pacific Microwave Conf. Proc., pp.1007-1010 (2002)

(40) K. Kawabata, H. Tampo, and Y. Kobayashi : "An improvement of perturbation method for the complex permittivity measurement of liquids", Asia-Pacific Microwave Conf. Proc. (2003) < to be published>

$<$ 高温超電導体の評価方法 $>$

(Hakki-Coleman 法の応用)

(41) Z. Y. Shen, C. Wilker, P. Pang, W. L. Holstein, D. W. Face, and D. J. Kountz : "High $\mathrm{T}_{\mathrm{c}}$ superconductor- sapphire resonator with extremely high Q-values up to 90K", IEEE Trans. Microwave Theory Tech., Vol.MTT-40, pp.2424-2432 (1992)

(42) J. Krupka, M. Klinger, M. Kuhn, A. Baranyak, M. Stiller, J. Hinken, and J. Modelski : "Surface resistance measurements of HTS films by means of sapphire dielectric resonators", IEEE Trans. Appl. Supercond., pp. 3043-3048 (1993)

(43) N. Tellmann, N. Klein, U. Dähne, A. Scholen, H. Schulz, and H. Chaloupka : "High-Q $\mathrm{LaAlO}_{3}$ dielectric resonator shielded by YBCO-films", IEEE Trans. Appl. Supercond., Vol.4, No.3, pp.143-148 (1994)

(44) J. Mazierska : "Dielectric resonator as a possible standard for characterization of high temperature superconducting films for microwave applications", Journal of Supercond., Vol. 10, pp. 73-84 (1997)

(45) D. W. Face, F. M. Pellicone, R. J. Small, L. Bao, M. S. Warrington, and C. Wilker : " $\mathrm{Tl}_{2} \mathrm{Ba}_{2} \mathrm{CaCu}_{2} \mathrm{O}_{8}$ and $\mathrm{YBa}_{2} \mathrm{Cu}_{3} \mathrm{O}_{7}$ films on large area $\mathrm{MgO}$ and sapphire substrates for high power microwave and rf applications", IEEE Trans. Appl. Supercond., Vol.9, pp.2492-2495 (1999)

(2 サファイア円柱共振器法)

(46) Y. Kobayashi, T. Imai, and H. Kayano : "Microwave measurement of current dependence of surface impedance for high- $T_{c}$ superconductor", IEEE Trans. Microwave Theory Tech., Vol.39, No.9, pp.1530-1538 (1991)

(47) H. Yoshikawa, S. Okajima, and Y. Kobayashi : "Comparison between BMT ceramic one-resonator method and sapphire two-resonator method to measure surface resistance of YBCO films", Asia-Pacific Microwave Conf. Proc., pp.1083-1086 (1998)

(48) Y. Kobayashi, H. Yoshikawa, and T. Hashimoto : "Frequency dependence of measurement precision in two dielectric resonator method for estimating surface resistance of high- $T_{c}$ superconductor films", Asia-Pacific Microwave Conf., pp.1564-1567 (2000)

(49) IEC 61788-7 (2001) : Superconductivity -Part 7: Electronic characteristic measurements- surface resistance of superconductors at microwave frequencies

(50) T. Hashimoto and Y. Kobayashi : "Design of sapphire rod resonators to measure the surface resistance of high temperature superconductor films", IEEE MTT-S Int. Microwave Symp. Dig., TH4E-6, pp.1975-1978 (2002)

(1 サファイア円柱共振器法)

(51) T. Hashimoto and Y. Kobayashi : "A novel technique to measure frequency dependence of surface resistance of YBCO films using some modes in a sapphire rod resonator", $32^{\text {nd }}$ European Microwave Conf. Dig., pp.263-266 (2002)

(52) T. Hashimoto and Y. Kobayashi : "Measurements of frequency dependence of surface resistance of HoBCO films using some modes in a sapphire rod resonator", Asia-Pacific Microwave Conf. Proc., Vol.1, WE3D-1, pp.203-206 (2002)

(53) T. Hashimoto and Y. Kobayashi : "Frequency dependence measurements of surface resistance of superconductors using four modes in a sapphire rod resonator", IEICE Trans. Electron., Vol.E86-C, No.8, pp.1721-1728 (2003)

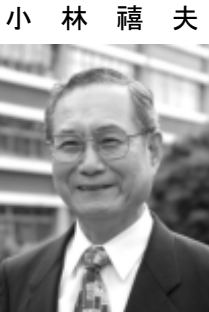

（正員） 1939 年 7 月 4 日生。 65 年 3 月東京都 立大学大学院工学研究科修士課程修了。同年 4 月埼玉大学工学部助手, 68 年講師, 82 年助教 授を経て 88 年同教授。工博。誘電体共振器 · フィルタ, 低損失誘電体および高温超電導材料 のマイクロ波・ミリ波測定の研究に従事。95 年第 20 回井上春成賞受賞。IEEE Fellow，電子 情報通信学会フェロー。 